\title{
Can Humans Tell Spring?
}

By Robin Redbreast

Other birds intrigued by that time-honored question, Can Humans Recognize Spring? may find some observations of mine of interest.

While out human-watching on a sunny April afternoon I was lucky enough to see an entire family of humans emerge from their nest. I had an excellent view (being hidden in a tree only 150 yards from them) and saw the whole of their antics.

Old Man Human, whose dress is much the drabbest of the family (and who, I noticed, is also distinguished from the Female by marks under his eyes, circular in shape), came hopping out of his nest carrying a rakeshaped piece of wood. The Old Man Human hops chiefly on his heels. Hop, hop he went with rake, as though combing grass.

After perhaps 15 minutes of this, Old Man Human threw down the rake and uttering croaks which sounded like: o-my-bak, o-my--bak, o-mybak, he hopped into the nest.

Meanwhile the Female Human had been digging and poking in the earth, pulling out bits of grass and weeds. While at this she was joined by another Female and the two, making a 'my-dear my-dear, my-dear' kind of cry, hopped into the nest.

The young Humans who had all this time been going through little tricks, such as skipping (there is no other word for it!) over a piece of rope, or running after one another with bits of wood, chirping, "bangbang-yoor-ded," on a suddien came to a full stop and crying together, "teevee, tee-vee, tee-vee," all flew into the nest.

This queer behavior in April which I have never witnessed at any other time of year, seems to me to give weight to the idea that Humans DO have a sense of spring.

Reprinted from Barry Mather's column "Mather's Nightcap" in the Vancouver Sun, April 17, 1955

\section{Summer Meeting at Emma Lake}

\section{June 14 and 15, 1958}

Emma Lake is a well-known lake containing along its shores some eight summer resorts. It is located about 30 miles north of the city of Prince Albert on a paved highway. The lake is very crooked, about six miles long and three miles wide, with a water area of about eight square miles. This lake is in the midst of the Parkland Zone and surrounding it may be found all types of forests known to this zone along with some small excursions of the Northern Coniferous Forest. The area has all types uf habitat and shelters an extensive community of birds, mammals and other forms of life. The botani. will find a wide variety of plants, both vascular and otherwise.

The Prin e Albert Natural History Society is in chorge of arrangements. The programme being planned for tne meeting will emphasize various aspects of forestry-foresit inventory, forest pathology, game management, fish biology, and forest entomology. It is hoped to have at least one field trip under qualified foresters. Bird watchers, too, will have trips arranged for them.

It is expected that there will be ample accommodation at MacIntosh Point for all members who wish to attend. However, since this meeting will be held in advance of the regular season, the Prince Albert Society must have advance notice of your coming. Accomodation will be largely in cabins whose size and fittings greatly influence the rates, making exact quotations difficult. Dishes and cooking facilities are provided, but bedding should be brought by the renter of the cabin. Rates range from $\$ 3.00$ to $\$ 8.00$ a day.

A store is located at Christopher Lake, five miles from MacIntosh Point. For those not doing their own cooking, meals will be served in the dining room of the hotel at fixed hours. Meal charges of $\$ 1.10$ per meal must be paid in advance. A lunch on Saturday will be available for those on the field trip and can be bought at the time. 